\title{
Território em disputa: a escola na luta entre o republicanismo e a Igreja em Portugal (séculos XIX e XX)1
}

Disputed territory: the school and the struggle between republicanism and the Church in Portugal (19th and 20th centuries)

Patricia Santos Hansen*

\section{Resumo}

O trabalho tem como objetivo discutir conceitos centrais aos processos de secularização e laicização do ensino em Portugal desde a Monarquia Constitucional até o início da Primeira República. A abordagem parte da compreensão dos espaços escolares públicos e privados como territórios, dos quais Estado e Igreja procuraram estrategicamente se apropriar a fim de conquistar e afirmar uma hegemonia política e cultural sobre a sociedade portuguesa.

Palavras-chave: Escola laica; Primeira República (Portugal); história da educação.

\begin{abstract}
This paper aims to discuss some of the core concepts underlying the processes of secularization and laicization of education in Portugal, from the Constitutional Monarchy to the beginning of the First Republic. I will consider public and private school spaces as territories, which both state and Church sought to strategically move to conquer and to establish political and cultural hegemony in Portuguese society.

Keywords: secular school; First Republic (Portugal); history of education.
\end{abstract}

Essencial nas ciências sociais e humanas, o conceito de território não se confunde com o conceito de espaço nem se restringe a ele, da mesma forma que não é sinônimo de região, lugar ou local. Conceito denso, complexo e polissêmico, território remete às disputas e ao exercício do poder. Nas palavras de Foucault: "território é sem dúvida uma noção geográfica, mas é antes de tudo uma noção jurídico-política: aquilo que é controlado por um certo tipo de poder".

\footnotetext{
* Instituto de Educação da Universidade de Lisboa (IEUL). Alameda da Universidade, 1649-013 Lisboa

- Portugal.patriciahansen@ie.ul.pt
} 
É nesse sentido que o conceito de território pode ser útil para pensar a laicização dos espaços escolares em Portugal, como uma espécie de corolário do radical processo de secularização conduzido pelo republicanismo neste país.

É notório que as relações entre o Estado e a Igreja foram conturbadas desde a Época Pombalina, quando o marquês promoveu as famosas reformas que culminaram na expulsão dos jesuítas do Império, até então os principais aliados da Monarquia portuguesa na empresa colonizadora. Segundo Falcon, tais reformas, contudo, não tinham tanto um cariz anticlerical e estavam mais ligadas às questões políticas do que às religiosas. Acabaram por fazer parte do amálgama que o autor chamou de 'cristianismo ilustrado'.

A Constituição de 1822 "em nome da Santíssima e Indivisível Trindade”, que inaugura a Monarquia Constitucional, e a Carta de 1826 outorgada por "Dom Pedro por graça de Deus, Rei de Portugal e dos Algarves, etc." afirmariam a continuação da "Religião Católica Apostólica Romana”. Em 1822 como "Religião da Nação" e em 1826 como "Religião do Reino", ${ }^{5}$ ainda que fosse permitido aos estrangeiros o "exercício particular de respectivos cultos" (1822), e "em casas para isso destinadas, sem forma alguma exterior de Templo" (1826). Nas "disposições gerais, e garantias dos direitos civis e políticos dos cidadãos portugueses" a Carta de 1826 garantia ainda que "ninguém pode ser perseguido por motivos de Religião, uma vez que respeite a do Estado, e não ofenda a Moral Pública”.

Os textos constitucionais, entretanto, não deixam de espelhar as contradições do liberalismo português em relação aos princípios da liberdade de consciência e de expressão. Exemplos disso eram os juramentos do Rei, deputados, conselheiros de Estado e outros em que "manter a Igreja Católica Apostólica Romana" tinha precedência sobre "guardar e fazer guardar a Constituição”. Também a organização das eleições pelos párocos, encarregados das listas de eleitores e realizadas nas igrejas e seguidas de missas, não favorecia em nada as liberdades individuais. Além disso, deve-se notar que a tolerância a outras religiões estava prevista apenas para 'estrangeiros', de modo que os nacionais não pareciam usufruir do direito de escolher sua própria religião. Em outras palavras, tanto o exercício da cidadania quanto a identidade nacional, ou seja, o pertencimento à "comunidade política imaginada" ${ }^{6}$ portuguesa ainda eram indissociáveis não somente do credo cristão como da lealdade à Igreja Católica Romana.

Por isso, também, não é de estranhar que no que diz respeito à formação dos cidadãos, as componentes de intenção socializadora dos currículos da escola primária, segundo Pintassilgo, "vão-se suceder, numa curiosa dialética 
continuidade-ruptura: moral e religião cristã, civilidade, direitos e deveres do cidadão e, finalmente, educação cívica (e moral), entre outras formulações". ${ }^{7}$

Contudo, não obstante ter predominado a noção da importância do cristianismo para a formação civil, moral e ética, as posições dos liberais em relação à Igreja e à Religião não foram de forma alguma consensuais ao longo do século XIX.

As manifestações mais evidentes dos conflitos de interesses entre liberais e a Igreja acabaram tomando por alvo privilegiado as congregações religiosas, justamente a fração do clero que mantinha colégios, hospitais, obras de assistência etc. Como diz Vítor Neto, "a maioria dos deputados do nosso primeiro liberalismo era defensora de uma reforma das ordens religiosas que reduzisse o seu peso na sociedade, e, após a Guerra Civil de 1832-1834, os parlamentares apoiaram as medidas que extinguiram as congregações religiosas masculinas e reformaram as femininas. De modo que o anticlericalismo liberal era mais uma forma de anticongreganismo do que uma luta contra o clero secular". ${ }^{8}$

O decreto de 1834 que extinguia as ordens religiosas masculinas não impediu que durante o século XIX 'progressivamente e de forma discreta' as congregações acabassem por regressar a Portugal. Não seria um processo pacífico, contudo, como demonstra o significativo episódio das Irmãs de Caridade francesas pertencentes à Ordem de São Vicente de Paulo que, tendo entrado em Portugal em 1857 sob o pretexto de prestar serviços de assistência, acabaram por ser obrigadas a abandonar o país 5 anos depois por uma nova proibição de funcionamento das congregações religiosas, sem deixar de ser durante esse tempo alvo de uma violenta campanha anticlerical. As irmãs francesas, porém, estavam longe de serem as únicas a tentar se estabelecer no país. De acordo com Maria Cândida Proença, "a partir da década de 1850, com o propósito de proceder à fundação de escolas, hospícios e hospitais entraram em Portugal jesuítas, franciscanos, padres do Espírito Santo, beneditinos, irmãos de S. João, irmãzinhas dos pobres, salesianos e lazaristas, entre muitos outros". 9

O caso das Irmãs de Caridade, porém, motivaria fortemente as discussões a respeito da influência religiosa no ensino a partir da década de 1850. Foi em razão disso que a proposta da Comissão Eclesiástica ao Parlamento seria aprovada, estabelecendo que os membros das congregações religiosas não poderiam ensinar nos estabelecimentos públicos, ainda que o clero secular o pudesse fazer. Mas os regulares poderiam ainda ensinar nos colégios particulares.

A discussão que distinguia fortemente as posições em relação ao clero regular e ao clero secular era balizada, por um lado, por argumentos nacionalistas e, por outro, por opiniões amparadas pelos princípios liberais. Exemplo 
do primeiro foi o projeto (derrubado) do deputado Vicente Ferrer que defendia "a proibição do ensino a todos os membros das ordens religiosas que tiveram a audácia de se estabelecer, ilegalmente, depois dos decretos de 1834 ... Ele entendia que as Irmãs da Caridade não poderiam ensinar, por estarem subordinadas a um prelado estrangeiro e por terem uma existência ilegal, uma vez que se achavam estabelecidas sem licença régia" (Neto, 2009, p.95). Defensores da segunda posição, contudo, argumentavam que os pais deveriam ter o direito de educar os filhos em escolas religiosas, caso assim o desejassem.

A própria dinâmica política e jurídica que determinou extinções, expulsões, restrições ou, em contrapartida, permitiu o regresso e o funcionamento das ordens religiosas é extremamente confusa. Em 1829, durante o governo de d. Miguel, os jesuítas expulsos por Pombal voltaram a se estabelecer em Portugal; em 1833 é criada uma Comissão de Reforma Eclesiástica que determina a supressão de conventos e mosteiros com menos de 12 religiosos e proíbe todas as admissões a ordens sacras e noviciados monásticos; em 1834 novamente os jesuítas são intimados a deixar Portugal, os conventos, mosteiros e outras casas religiosas masculinas são extintos e seus bens nacionalizados, determina-se que os cargos religiosos passem a ser preenchidos por concurso público e d. Pedro é excomungado pelo papa Gregório XVI; $;{ }^{10} \mathrm{em} 1841$ Portugal restabelece relações com a Santa Sé; em 1848 um convênio entre Portugal e a Santa Sé possibilita o reingresso de ordens religiosas em Portugal; em 1862 há uma nova proibição de funcionamento das congregações religiosas; em 1870, após o Concílio Vaticano I, há uma nova tentativa de reintrodução das ordens religiosas; em 1880 o governo determina que os governadores informem a existência de estabelecimentos de ensino pertencentes a congregações; em 1901 um decreto de Hintze Ribeiro permite a reconstituição das ordens religiosas que se dedicassem exclusivamente à instrução, à missionação nas colônias ou à caridade.

De qualquer modo, se a princípio a maioria dos liberais não parecia querer romper com as crenças tradicionais, ao longo do século iria crescer o número dos que percebiam a influência religiosa na educação como um efetivo obstáculo à liberdade de consciência. Com isso crescia também o número daqueles que denunciavam a associação entre influência católica e decadência ou atraso nacional.

Sobre a clivagem que essa nova consciência acaba por representar, vale lembrar com Fernando Catroga que, se desde a Idade Média podem-se observar diversos movimentos de secularização das sociedades, o Iluminismo iria provocar a sua intensa aceleração e somente as condições políticas e ideológi- 
cas do século XIX permitiriam que esse processo assumisse uma orientação laicizadora, ou seja, que dele surgisse uma "contestação militante apostada em pôr em causa a força institucional, cultural e simbólica do cristianismo e do catolicismo". ${ }^{11}$ Isso também quer dizer que "se toda a laicidade é uma secularização, nem toda a secularização é uma laicidade". ${ }^{12}$

Referência incontornável sobre o assunto, aliás, Catroga ressalta em vários textos as diferenças entre secularização e laicização, vocábulos frequentemente usados como sinônimos (cf. Catroga, 1988; 2004; 2006; 2010). Vale lembrar que significados e diferenças específicos ganham sentido apenas em determinados contextos históricos, caso de Portugal a partir do século XIX, em que essa distinção é fundamental para compreender as condições do debate que então se fazia em torno da educação. E é somente após o surgimento dessa 'contestação militante' a favor da laicização da sociedade portuguesa e assumida pelo republicanismo, que o espaço escolar assume efetivamente o caráter de 'território em disputa', conforme iremos argumentar.

Secularização, de acordo com Catroga, referencia "o caminho que veio a desaguar na Modernidade, provocando a progressiva autonomização da razão, da natureza, da sociedade e da política, assim como a imanenticização dos fundamentos da ética e da liberdade, e a paulatina separação da esfera pública e privada" (Catroga, 2004, p.52). Trata-se, portanto, de um conceito abrangente que como o mesmo autor aponta, teve sua gênese em meados do século XVI na França, em referência a uma situação bastante específica de "arresto de bens da Igreja por parte da coroa" (ibidem, p.57). Sentido que não deixou de estar associado à secularização ainda no século XIX português, tomando-se por exemplo a lei de 1834 que determinou a extinção das casas religiosas masculinas e a respectiva nacionalização de seus bens.

Laicidade e laicização, por sua vez, palavras cujo prefixo seria primeiramente utilizado em expressões opostas aos termos clerical e clericalismo, assumiriam o sentido mais geral de oposição "a todo universo de referência confessional ou simplesmente religiosa". ${ }^{13}$ Ganhando força no contexto do republicanismo francês em fins do século XIX esses termos teriam suas definições em dicionários associadas desde logo ao campo da educação e do ensino. Ainda segundo o mesmo autor essa aplicação explica-se, pois foi "nos inícios da década de 1870 que a laicidade ganhou curso dentro da querela sobre a secularização do ensino" (ibidem, p.98).

A evolução semântica do conceito tal como denunciavam os seus usos em fins do século XIX, portanto, não apenas apontava para uma ação mais positiva do Estado no sentido de laicizar a sociedade nos seus aspectos cul- 
turais, políticos, jurídicos e sociais, condição para a realização das promessas emancipatórias de fundo iluminista da Razão, da Ciência, do Progresso e da Civilização, como sugeria que a escola seria, por excelência, o espaço privilegiado dessa ação. Foi essa a principal bandeira levantada pelos republicanos portugueses à medida que o movimento ganhava corpo, a partir da década de 1870.

De fato, o ponto fraco das medidas anticongregacionistas dos liberais havia sido sempre o papel que as ordens religiosas cumpriam na educação, incluindo as missões do ultramar, e, como se verá, mesmo os republicanos terão dificuldades em prescindir totalmente da Igreja nas colônias. Em suma, expulsões, extinções e proibições não conseguiam neutralizar sua influência em razão da importância que lhes era reconhecida, pela sociedade e em larga medida pelos políticos, por sua atuação no ensino e na assistência. Tratava-se de áreas em que o Estado liberal não queria, não podia ou talvez não concebesse como, ocupar o lugar da Igreja.

Foi, portanto, o republicanismo com seu caráter 'messiânico', sua 'missão regeneradora', ${ }^{14}$ sua 'utopia demopédica' (Pintassilgo, 2010) que acabou por transformar o espaço escolar em território a ser disputado com a Igreja e 'apropriado' ${ }^{\prime 15}$ para o seu projeto laico. ${ }^{16} \mathrm{Um}$ espaço público no qual deveriam prevalecer os valores fundamentais do Estado republicano.

A própria noção de 'utopia demopédica', contendo a ideia de um (não) lugar, uma sociedade outra em que vigoram leis, regras e valores que permitem a formação de um 'homem novo' é rica para pensar a escola como um território a ser apropriado pela República. Não é coincidência que uma significativa parte da literatura cívico-pedagógica de fins do século XIX em vários países, pois que fortemente comprometida com os diversos processos de formação nacional, tenha escolhido o ambiente escolar como o cenário privilegiado de suas narrativas de formação.

Tendo como melhor exemplo o Coração de Edmondo de Amicis, a literatura de ficção frequentemente representou a escola como a miniatura de uma sociedade perfeita, como se formados naquele ambiente os futuros cidadãos ao deixar a escola fossem capazes de construir/reproduzir a perfeição social em escala nacional. ${ }^{17}$ Assim, o espaço escolar (utópico) tornou-se talvez a principal metáfora da nação imaginada sob a República.

Enfatizando ainda a questão da apropriação dos espaços escolares como eixo de reflexão para compreender as disputas entre Estado e Igreja, vale ressaltar, conforme Sérgio Campos Matos em texto sobre a escola privada nos séculos XIX e XX, que existem dois critérios quando se fala de 'escola particu- 
lar' em Portugal: “1) a propriedade da escola e 2) o tipo de ensino, envolvendo autonomia em relação ao sistema de ensino público". ${ }^{18}$ A diferença entre essas duas concepções está no cerne dos conflitos que em várias ocasiões dividiram os próprios republicanos.

Desde a sua organização o movimento republicano em Portugal, com a fundação de centros republicanos, destacou o lugar privilegiado e estratégico atribuído à educação em seu projeto político. Os centros deveriam ter "uma ação predominantemente pedagógica, a par da militância política determinada pelas necessidades da luta eleitoral. Eram, assim, associações híbridas, uma mistura de sociedades de pensamento, comitês eleitorais, escolas e núcleos protopartidários". ${ }^{19}$

Até o final da monarquia foram criados 160 centros, quase a metade dos quais nas cidades de Lisboa e Porto. ${ }^{20}$ A própria existência de escolas ligadas aos centros, assim como os registros de várias ações educativas neles promovidas, se não permitem compreender o significado mais profundo da educação no ideário republicano português, são indiscutivelmente testemunhos da relevância e da centralidade do assunto para grande parte dos homens que abraçaram a causa naquele momento.

Além disso, outras iniciativas também anteriores ao advento do regime em 1910 e direta ou indiretamente ligadas ao republicanismo, como a Escola Oficina $\mathrm{n}^{\circ}$ 1, fundada em 1905 por uma aliança entre republicanos e maçons, o projeto das Universidades Populares, as "Escolas Móveis pelo Método de João de Deus", criadas em 1882 e mantidas em funcionamento após o 5 de outubro, e a forte associação entre a propaganda republicana e a defesa da escola laica como única forma de libertar a sociedade da influência clerical, somam-se como indícios do modo como o problema parecia delinear-se, sobretudo, como uma questão de caráter territorial, ou seja, como se a conquista e, subsequentemente, o domínio e a apropriação pelo republicanismo dos territórios/espaços escolares fossem as condições primordiais da liberdade das consciências.

As Escolas Móveis, aliás, são um bom exemplo disso. O decreto de 29 de março de 1911 compreendia que essas escolas seriam uma alternativa válida à escola primária fixa nos lugares onde esta não existia. E, segundo Moura, a "confiança que os republicanos depositavam nessas escolas, onde o espírito de militância parecia ter maior peso que a preparação pedagógica e científica, ofendia os professores colocados na carreira normal, que viam no recrutamento desses 'missionários' - fundamentado na confiança ideológica e não na preparação acadêmica - uma ameaça à sua própria existência". ${ }^{21} \mathrm{~A}$ 'republica- 
nização' dos espaços escolares, fossem eles fixos ou móveis, portanto, era o que traduzia a sua territorialização.

Pensemos nas imagens suscitadas pelos títulos escolhidos por Moura para seu livro A Guerra Religiosa na I República e ainda mais especificamente para o capítulo em que trata da educação: "Na frente do combate - a escola" (Moura, 2004). Sem desenvolver no corpo do texto o argumento da disputa territorial, os títulos sugerem intuitivamente quase a mesma hipótese que aqui se levanta.

Isso explica, para além da importância do ensino primário (obrigatório, gratuito e laico) e da escola primária como lugar por excelência de socialização de todos os portugueses, os esforços de neutralização da influência religiosa na educação que por vezes ultrapassaram os limites entre o público e o privado, contrariando assim um dos princípios caros ao liberalismo.

O primeiro e principal alvo das contestações era claramente a 'escola confessional'. Se a extinção das ordens religiosas promulgada três dias após a proclamação da República em 8 de outubro de 1910 representou um forte golpe no ensino confessional, uma sequência de leis, decretos e diplomas daria continuidade a esse esforço. O decreto de 22 de outubro, por exemplo, declarava "extinto nas escolas primárias e normais primárias o ensino da doutrina cristã". ${ }^{22} \mathrm{O}$ de 31 de dezembro, procurando dificultar quaisquer resistências ao cumprimento do anterior, proibia o exercício do ensino ou o trabalho em qualquer estabelecimento de ensino aos membros das congregações religiosas que, sendo de nacionalidade portuguesa, puderam continuar residindo como secularizados no país, após a extinção das respectivas ordens. ${ }^{23}$ A Lei da Separação do Estado das Igrejas, de 20 de abril de 1911, que finalmente afirmava que a religião católica apostólica romana deixava de ser a religião do Estado e reconhecia e garantia "a plena liberdade de consciência a todos os cidadãos portugueses e ainda aos estrangeiros que habitarem o território português", pouco tratava do ensino e da escola. Contudo, os poucos artigos em que remete a essas questões merecem reflexão.

No artigo 53 a Lei da Separação determinava que "as crianças em idade escolar, que ainda não tiverem comprovado legalmente a sua habilitação em instrução primária elementar, não podem assistir ao culto durante as horas das lições". No artigo seguinte estabelecia que a "infração ao disposto no artigo antecedente importa a pena de desobediência simples para o pai do menor, ou, na sua falta ou ausência, para quem exercer o poder paternal, e a de desobediência qualificada para o ministro da respetiva religião, um e outro desde que sejam convencidos de ter contribuído, por ação ou omissão, para o fato ali proibido" (citado em Proença, 2011, p.289). A lei, portanto, não somente con- 
firmava a obrigatoriedade do ensino, como sublinhava a precedência do Estado sobre a religião.

Essas medidas seguiam de perto o que Jules Ferry havia feito anos antes na França, não sem provocar fortes reações entre os conservadores para quem "o reconhecimento do princípio da obrigatoriedade significava uma intromissão do poder estatal em algo que era do foro privado, ou, como dizia o duque de Broglie, uma intolérable violation du foyer domestique" (em Catroga, 2010, p.240).

No entanto, intromissões como essa por parte do Estado em assuntos pertencentes ao 'foro doméstico', ou seja, tradicionalmente sujeitos ao governo do pater familiae, foram comuns a todos os processos de consolidação dos Estados modernos. Em cada país, porém, seriam tingidas com as cores próprias aos diferentes contextos nacionais e ideologias de Estado.

Tal avanço do poder estatal a partir do século XIX deixaria fortes marcas na história da infância e da família que, como ressalta Michelle Perrot, "vê sua autonomia ameaçada pela crescente intervenção do Estado, o qual, não podendo agir constantemente em nome dela, vem a ocupar seu lugar, especialmente na gestão da criança, o ser social e o capital mais precioso". ${ }^{24}$ Mais adiante, explica a mesma autora, "o filho não pertence apenas aos pais: ele é o futuro da nação e da raça, produtor, reprodutor, cidadão e soldado do amanhã. Entre ele e a família, principalmente quando esta é pobre e tida como incapaz, insinuam-se terceiros: filantropos, médicos, estadistas que pretendem protegê-lo, educá-lo, discipliná-lo" (1999, p.148).

Nunca será demais enfatizar a importância dessa mudança nas sensibilidades que, ao transformar a criança em metáfora de futuro, subverteu escalas de valores sociais fortemente estabelecidos. Se até então, nas dimensões política e social, valorizava-se mais a ancestralidade, os mais velhos, a experiência e a tradição, essa subversão de valores faz que aos poucos sejam cada vez mais privilegiados os descendentes, a juventude, o novo e, enfim, as promessas de futuro. Como resultado desse movimento, a infância em diversos contextos nacionais passaria a ser vista fundamentalmente como um 'projeto'. ${ }^{25}$

Ainda sobre a Lei da Separação, no que diz respeito à educação vale observar o artigo 189, que autorizava "o Governo a reformar os serviços do Colégio das missões ultramarinas, de modo que a propaganda civilizadora nas colônias portuguesas, que haja de ser ainda feita por ministros da religião, se confie exclusivamente ao clero secular português, especialmente preparado para esse fim em institutos do Estado" (citado em Proença, 2011, p.312). 
Em outras palavras, no que se refere aos territórios coloniais a laicização (e a consequente republicanização) não era uma prioridade do Estado, limitando-se este, por meio da religião, a procurar reforçar os laços de lealdade no Ultramar para com a pátria portuguesa, baseando-se para isso na ação do 'clero secular português' preparado em 'institutos do Estado'. Essa medida, se era ainda coerente com o anticongregacionismo das ações secularizadoras praticadas desde a Monarquia Constitucional, nada tinha em comum com as políticas de educação implementadas em Portugal pela República.

A Constituição de 1911 viria reforçar aquele avanço do poder Estatal sobre o âmbito privado, ao afirmar no artigo 10 que o "ensino ministrado nos estabelecimentos públicos e particulares fiscalizados pelo Estado será neutro em matéria religiosa". Se esse artigo visava garantir a neutralidade ou laicidade do ensino, o artigo seguinte estabelecia ainda que o ensino primário elementar seria 'obrigatório e gratuito'. ${ }^{26}$

O radical projeto laicizador republicano, portanto, promoveria uma forte inflexão no acelerado processo de secularização vivido sob a Monarquia Constitucional. Tal projeto, contudo, ao tentar transformar a escola laica, por uma série de operações simbólicas e rituais, em 'templo' de uma nova 'religião cívica' acabou por dar as costas à ideia de neutralidade do ensino que ele próprio afirmava defender.

Na reforma da instrução primária de 1911 afirmava-se: “A República libertou a criança portuguesa, subtraindo-a à influência jesuítica, mas precisa agora de a emancipar definitivamente de todos os falsos dogmas, sejam os de moral ou os de ciência, para que seu espírito floresça na autonomia regrada, que é a força das civilizações".

Mas logo adiante o mesmo texto expressava algumas de suas contradições:

A religião foi banida da escola. Quem quiser que a dê à criança, no recanto do lar, porque o Estado, respeitando a liberdade de todos, nada tem com isso. A moral das escolas, depois que a República se fundou, só tem por base os preceitos que regulam a justiça entre os homens e a dignidade dos cidadãos. Varreu-se da pedagogia nacional todo o turbilhão de mistérios, de milagres e de fantasmas que regulavam, até então, o destino mental das crianças.

A escola vai ser neutra. Nem a favor de Deus, nem contra Deus. Dela se banirão todas as religiões, menos a religião do dever, que será o culto eterno desta nova igreja cívica do povo. ${ }^{27}$ 
Aparentemente a terminologia utilizada consagrava o ideal de 'escola neutra', remetendo as crenças e as práticas religiosas para os terrenos da consciência individual e da vida privada. Contudo, o que se verifica na prática e os debates no campo educativo deixam transparecer é que a situação era bastante mais complexa e logo os adversários da escola confessional assumiriam posições diferentes, muitas vezes ambíguas.

A maioria das opiniões era a favor da 'escola laica' por influência da experiência da III República na França, onde a articulação entre positivismo e republicanismo acabou por gerar um modelo de pedagogia republicana, difundido para além do ensino formal, que encontrou muitos adeptos não só em Portugal como também no Brasil.

João de Barros e Tomás da Fonseca colocaram-se claramente a favor da 'escola laica'. Para o primeiro, a 'educação moral na escola primária' tinha que ser 'laica', 'claramente afirmativa', ainda que não 'autoritária' ${ }^{28} \mathrm{Ou}$ seja, a 'escola laica' precisava formar a consciência das crianças com base num quadro de valores claramente explicitado.

Para Tomás da Fonseca a neutralidade da escola era impossível, pois, perante correntes diferentes ou opostas o professor tinha que assumir determinadas opções e demarcar-se de outras. Nesse sentido, concluía: "Só no laicismo pode fundar-se a única escola racional, científica, emancipatória e progressiva". ${ }^{29}$

A grande voz dissonante foi a do libertário Adolfo Lima, que defendeu com veemência a 'escola neutra'. Para Lima a 'escola laica' veiculava inevitavelmente os princípios políticos e filosóficos do Estado. "É o meio de o Estado preparar e moldar as gerações, afeiçoando-as ao seu modo de ser”, oferecendo "um novo credo laico" ${ }^{30}$ no lugar do credo católico. O próprio autor, no entanto, iria questionar a possibilidade de uma real neutralidade do ensino.

Em síntese pode-se dizer, conforme as palavras de Pintassilgo, que aquilo que no essencial parece separar a 'escola neutra' da 'escola laica' é:

[enquanto a] 'escola neutra' apenas procura separar os campos da educação e da religião, aceitando a livre existência das crenças e dos cultos religiosos, tendo por objetivo a formação de uma consciência livre e autônoma, a 'escola laica' caracteriza-se pela atribuição de um papel mais ativo e militante à escola, no sentido de contribuir para a gradual extinção das crenças religiosas, católicas, no caso, o que passa por uma restrição mais severa da difusão pública dos símbolos e das práticas religiosas do catolicismo. ${ }^{31}$ 
Na prática o vazio deixado pela erradicação dos símbolos e rituais associados ao catolicismo na escola e em outros espaços públicos seria preenchido por um conjunto de símbolos e rituais de inspiração laica, constituindo-se esses elementos em aspectos fundamentais da pedagogia republicana.

O culto da pátria, comemorações e cortejos cívicos, símbolos nacionais como a bandeira e o hino, os novos feriados laicos e outras representações simbólicas foram as armas mobilizadas pelos republicanos na batalha pelo coração e pela alma dos portugueses. Inspirada pela doutrina de Comte, a República portuguesa constituiu sua própria 'religião cívica'.

No âmbito escolar as ações de laicização e republicanização ocorreriam no currículo formal mediante a atribuição de importância à educação moral e cívica. Mas principalmente se realizaram pelo 'currículo informal' que levava os cultos da Pátria, dos heróis, da bandeira e do hino para fora das salas de aula.

Festividades como as festas da árvore e os desfiles de batalhões escolares deveriam ultrapassar os muros das escolas, procedendo, a partir do espaço escolar, a uma ocupação de outros espaços públicos e secularizados, como ruas, praças e parques, de onde a Lei da Separação havia banido as procissões e outras manifestações religiosas.

É nesse sentido que a religião cívica republicana seria fundamentalmente uma 'religião da pátria'. A pátria revestida de sacralidade é assumida como entidade unificadora do civismo republicano.

Nas palavras de Mona Ozouf: “Ainsi la patrie joue, dans l'école laique, le rôle réservé à Dieu dans l'école congréganiste". ${ }^{32} \mathrm{Ou}$, como diria a republicana Ana de Castro Osório ao explicar para as crianças a entrada de Portugal na Primeira Guerra Mundial: "O que é preciso é que dentro de Portugal haja uma só fé e um só ideal, um só ideal que corresponda à grande religião: - A Pátria acima de tudo". ${ }^{33}$

Figura interessante e singular no republicanismo português, Ana de Castro Osório incluiu em um de seus livros amplamente utilizados nas escolas uma pequena peça de teatro intitulada Um sermão do Senhor Cura, em que 'traduz' didática e estereotipadamente para as crianças, do ponto de vista republicano é claro, o embate entre os valores e as visões de mundo laicos e católicos tal como se apresentavam na sociedade portuguesa de seu tempo e que se expressavam fortemente na legislação educacional e laicizadora. ${ }^{34}$

A peça se constitui num diálogo entre duas personagens, Guilherme e Filipe, os quais deveriam ser representados por 'rapazes de 10 a 12 anos' segundo a indicação da autora. Já de início fica estabelecido o contraste entre os dois personagens: “À beira do caminho, Filipe está deitado à sombra duma árvore. 
Sujo e desmazelado como um pequeno vadio, espreita a rede que armou aos pássaros dentro da propriedade, que tem por vedação um pequeno muro. Guilherme vem entrando, limpinho e alegre, assobiando ou cantarolando, com a saca dos livros de estudante" (Osório, 1922, p.185).

No desenrolar da conversa entre o estudante Guilherme e o ignorante Filipe, o primeiro conhecendo explicações científicas para fenômenos naturais, o segundo contrapondo a essas explicações uma série de superstições, a figura da professora da escola é contraposta à do cura da aldeia.

O texto é fértil em oposições binárias: sujeira/limpeza (higiene); bondade/ maldade (com os animais); conhecimento/ignorância; estudo/vadiagem; trabalho/parasitismo social; ciência/superstição; razão/religião; professora/cura; mulher/sacerdote; escola/Igreja.

Obviamente as oposições sintetizavam o embate entre os valores com os quais os republicanos buscavam se associar e os que identificavam com a religião. Mas, para além disso, não era a peça um interessante instrumento de legitimação das investidas do Estado sobre a esfera privada, conforme os artigos da Lei da Separação e da Constituição de 1911?

Coincidência ou não, segundo Maria Lúcia de Brito Moura os jornais posteriores à legislação laicizadora da República registram com muita frequência as resistências ao cumprimento da lei no que diz respeito às escolas, assim como conflitos locais entre religiosos e professores. Não raro, denúncias do periodismo republicano induziram ao encerramento de escolas em várias localidades. Foi o caso de um semanário de Gondomar que publicou que na escola do "Círculo Católico" local ensinava-se a ler com livros de missa e novenas de Maria. Também em Figueira da Foz, o Colégio Liceu-Figueirense foi acusado pelos jornais $O$ Mundo e $A$ Voz da Justiça de ter organizado um banquete em honra da Imaculada Conceição em que a sala estava decorada com as cores da monarquia, azul e branco, sob pretexto de serem as cores da Virgem. À hora do jantar, "na presença de crianças, o diretor teria brindado pela integridade da fé dos comensais, lamentando que o governo da República atacasse a religião". ${ }^{35}$

Argumentando que o colégio seguia "uma orientação pedagógica e religiosa que estava em acordo com a vontade dos pais, que lhe confiavam os seus filhos", o diretor acabou forçado a encerrar o Liceu e mudou-se para a Bélgica, onde abriu um colégio de instrução primária e secundária destinado a receber alunos portugueses e "garantindo que a despesa nesse estabelecimento de ensino não seria superior à que era feita em Portugal. As viagens eram realizadas por conta do colégio" (Moura, 2004, p.439). 
O significativo número de casos denunciados pelos jornais republicanos evidencia que as famílias resistiam às medidas do governo e continuavam mandando seus filhos para colégios onde receberiam educação religiosa. Mesmo sob condições adversas, membros do clero continuavam fundando escolas em suas paróquias.

Há que se considerar até mesmo a resistência de republicanos que divergiam da radicalidade das medidas laicizadoras no campo do ensino.

Um parecer da Comissão Central da Execução da Lei da Separação, em julho de 1912, dizia que não podia existir no país "qualquer colégio ou instituto de instrução ou educação” onde fosse ministrado o ensino religioso ou confessional. Assim, não era "permitida a catequese e a celebração de quaisquer atos de culto católico dentro de quaisquer casas de ensino" (ibidem, p.442).

Sobre a proibição do ensino religioso em um colégio feminino em que aparentemente havia muitas filhas de republicanos, Alfredo Pimenta argumentava no jornal República "que se estava a violar a Constituição. [E] Perguntava: 'é ou não lícito ensinar-se em Portugal o credo de qualquer religião? É ou não lícito o ensino do catolicismo em Portugal? Há para aí quem saiba esclarecer o caso?"' (ibidem, p.443).

Sobre os conflitos entre párocos e professores, devem-se considerar as fortes representações republicanas da figura do professor como apóstolo do livre pensamento e da razão (como aliás o texto de Osório já citado bem o demonstra) assim como a relevância que o Estado republicano atribuía a esses profissionais na concretização de seu projeto nacional, não é de estranhar que muitas vezes as famílias resistentes à laicização do ensino dirigissem aos professores seus ódios e ressentimentos.

Mas também é certo que o novo regime e toda a legislação que seguiu a sua instituição alteraram muito rapidamente as relações de forças existentes, o que foi sentido principalmente pelas populações de localidades menores.

Mais uma vez seguindo o levantamento e a análise de Brito Moura, em dezembro de 1910 o pároco de Vila de Ala, no concelho de Mogadouro, "foi intimado a comparecer na administração do concelho, por ter sido alvo de denúncia por parte de uma professora. $\mathrm{O}$ padre em questão era acusado de ter censurado a docente, na missa conventual, ameaçando-a mesmo com a demissão do seu cargo, por não ministrar a religião às crianças" (ibidem, p.452). Se nesse caso o padre foi obrigado a prestar contas ao governo - e houve muitas acusações a padres e leigos, apontando tentativas de desviar as crianças das escolas -, a maior parte dos casos recolhidos pela autora nos periódicos da 
época, contudo, dizia respeito à hostilidade da própria população em relação aos professores.

Um professor de Monsanto queixava-se, em carta ao periódico Educação Nacional, de que em sua povoação havia sido feita uma recolha de assinaturas pela sua transferência 'visto ofender, com a sua irreligiosidade' o sentimento católico dos habitantes do povoado.

Um professor de Vila Nova da Rainha, no concelho de Tondela, escreveria para outro periódico denunciando que o pároco incitava seus fiéis contra ele, a ponto de vir recebendo ameaças de morte.

Em 1914 numa aldeia do concelho de Mação o casamento civil de uma professora disparou uma campanha do pároco que era acusado de "tudo fazer para que as alunas da professora deixassem de ir à escola. Pela aldeia espalhava-se que as crianças que continuassem a ir às aulas, bem como os seus pais, seriam condenados às penas eternas" (ibidem, p.453).

Finalmente, assim como no diálogo republicano de Osório, os católicos também iriam recorrer à ficção para fazer representar seus valores de maneira didática, conforme o demonstra o semanário A Guarda, que publicou o seguinte diálogo para ilustrar os malefícios de uma escola 'sem Deus' e 'sem religião':

Um dos intervenientes era um honrado camponês, preocupado porque um dos filhos, que frequentava a escola, lhe confessara, depois de muita insistência - visto que ele e os seus companheiros estavam proibidos de contar no exterior o que se passava na aula - que o professor ensinara que Deus não existia, a religião servia apenas para enganar os papalvos, céu e inferno eram invenções dos padres. O camponês era de opinião que a escola tornava os filhos desobedientes. Pensara mesmo em retirá-los, pois sabia que "filhos sem religião são sempre os algozes e os tormentos dos pais". O seu interlocutor não o aconselhou nesse sentido - talvez por prudência. Advertiu-o, sim, de que devia mandar os filhos à catequese, para compensar a influência perniciosa da escola. (ibidem, p.456)

As resistências ao ensino laico e talvez mais ainda às perseguições ao ensino confessional mantiveram-se durante toda a Primeira República. Aos poucos, porém, o governo republicano teria de ir cedendo ou pelo menos fechando os olhos para as ilegalidades. No caso de determinadas escolas particulares, diz Moura, "parece ter havido consenso no sentido de que o Estado não devia intervir. É certo que continuavam a existir escolas onde se ministrava ensino religioso e sobre as quais nem os mais intolerantes se atreviam a levantar críticas, pelo menos de forma audível. Existiam os colégios dirigidos por congre- 
gações estrangeiras, protegidos pelas legações dos seus países, e perante as quais o Governo fora forçado a contemporizar" (ibidem, p.460).

Além desses que se mantinham na clandestinidade havia também os que criavam estratégias para escapar à fiscalização, como o Instituto Anglo-Português ligado às Doroteias. E, por fim, havia os colégios que obrigados a encerrar suas atividades em Portugal estabeleciam-se em outros países contando que seus alunos seguiriam com eles. Um caso curioso é o do Colégio de Santa Clara, de Valença do Minho, que após ser encerrado voltou a reabrir bem perto, em Tuy, na fronteira do lado da Espanha.

De modo geral, pode-se dizer que se os anos iniciais da República foram de confronto aberto contra a Igreja, a partir da entrada de Portugal na Primeira Guerra Mundial a situação começou a se modificar.

Antes de tudo, não era tempo de dissipar as forças ou de insistir em questões que dividiam a sociedade, e a Guerra obviamente desviava a atenção até mesmo dos mais aguerridos defensores da laicização para assuntos mais prementes.

Em 1914 começou-se a debater no Parlamento a possibilidade de reformas na Lei da Separação que, entretanto, só ocorreriam por iniciativa do Executivo em 1918.

Nesse período, contudo, as relações do governo com a Igreja foram se tornando mais suaves. As relações diplomáticas com a Santa Sé, que haviam sido rompidas em 1913, foram restabelecidas e o governo republicano foi obrigado a rever sua posição sobre as missões coloniais e o Padroado. Além disso, a aliança política entre católicos e monarquistas começava a se desfazer.

Em 1922, o $2^{\circ}$ Congresso Nacional Católico aprovava a decisão de o Centro Católico não mais se aliar a qualquer partido político, devendo apenas obedecer aos poderes instituídos e à Igreja.

Antes disso, em 1917, a grande repercussão pública das 'aparições' de Fátima dariam novo impulso à fé popular fazendo surgir as peregrinações que, ao lado do reaparecimento de cerimônias tradicionais como procissões e outros rituais da Semana Santa, a partir de 1919, suscitam discussões sobre a volta dos atos de culto público. Tudo isso alimentaria as crescentes demandas dos católicos pela reintrodução do ensino religioso nos colégios privados que em 1922 seria proposta pelo próprio ministro da Educação. As intensas polêmicas levantadas, porém, acabariam levando à demissão do ministro.

A Igreja teria que esperar pelo fim da Primeira República, em 1926, para ter, apenas parcialmente, restituídos os territórios físicos e simbólicos que perdera para o Estado laico. 
Pródiga na criação de símbolos e rituais laicos que deviam promover a interiorização dos valores republicanos pelos futuros cidadãos e gerar adesão afetiva à República pela via da religiosidade cívica, a Primeira República deixou sua marca inscrita no território escolar. A herança daquele projeto educacional cívico e laicizador permaneceria em muitas das tradições escolares que assumiriam inevitavelmente novos significados. Com a reintrodução da religião, o novo patriotismo seria, afinal, o produto de um sincretismo que se realizaria especialmente na escola.

\section{NOTAS}

${ }^{1}$ Este texto serviu de base para a parte que me coube na comunicação "A laicização da sociedade e da escola em Portugal”, apresentada em conjunto com o prof. Joaquim Pintassilgo no V Colóquio Internacional da Rede SPICAE (Grupo Interuniversitário de Investigação em História Comparada da Escola na Europa do Sul) que se realizou no Instituto de Educação da Universidade de Lisboa entre 3 e 5 de maio de 2012. Agradeço ao prof. Pintassilgo o convite e a confiança que acabaram por motivar este trabalho, assim como a leitura generosa da primeira versão deste texto.

${ }^{2}$ FOUCAULT, M. Microfísica do poder. 11.ed. Rio de Janeiro: Graal, 1995. p.157. Existe uma ampla produção acadêmica sobre o conceito de território e distintas abordagens. Para uma síntese breve e acessível cf. HAESBAERT, R. Da desterritorialização à multiterritorialidade. X ENCONTRO DE GEÓGRAFOS DA AMÉRICA LATINA, X., 20 a 26 mar. 2005, Universidade de São Paulo. Anais... Disponível em: www.planificacion.geoamerica.org/ textos/haesbaert_multi.pdf.

${ }^{3}$ FALCON, F. J. C. A Época Pombalina. São Paulo: Ática, 1993. p.97.

${ }^{4}$ CONSTITUIÇÃO de 23 set. 1822. Disponível em: debates.parlamento.pt/Constituicoes_ PDF/CRP-1822.pdf; Acesso em: 22 mar. 2012.

${ }^{5}$ CARTA CONSTITUCIONAL de 26 abr. 1826. Disponível em: debates.parlamento.pt/ Constituicoes_PDF/II\%20Carta\%20Constitucional.pdf; Acesso em: 22 mar. 2012.

${ }^{6}$ ANDERSON, B. Comunidades imaginadas: reflexões sobre a origem e a difusão do nacionalismo. São Paulo: Companhia das Letras, 2008.

${ }^{7}$ PINTASSILGO, J. A componente socializadora do currículo escolar oitocentista. In: $O$ particular e o global no virar do milénio: cruzar saberes em educação. Lisboa: Colibri; Sociedade Portuguesa de Ciências da Educação, 2002. p.549. Uma lista elaborada por esse autor com as reformas entre o final do século XVIII e o início do século XX e as respectivas disciplinas de caráter socializador que nelas estão previstas é bastante eloquente da importância imputada pelo liberalismo português ao catolicismo no que diz respeito à formação dos cidadãos. Observem-se as disciplinas introduzidas pelas seguintes reformas: Reforma Pombalina (1772): Catecismo e Regras da Civilidade; Reforma de 1836: Moral e Doutrina 
Cristã, Civilidade e Breves Noções da Constituição; Reforma de 1844: Princípios Gerais de Moral e Doutrina Cristã e Civilidade; Reforma de 1870: Educação Religiosa e Moral/ Doutrina Cristã e Noções de Constituição e dos Direitos e Deveres do Cidadão; Reforma de 1878: Moral e Doutrina Cristã (elementar), Moral e História Sagrada (complementar) e Direitos e Deveres do Cidadão (complementar); Reforma de 1894: Doutrina Cristã e Preceitos de Moral (elementar), Moral (elementar- $\left.2^{\circ} \mathrm{Grau}\right)$, Direitos e Deveres dos Cidadãos (complementar) e Moral e História Sagrada (complementar); Reforma de 1901: Doutrina Cristã e Preceitos de Moral e Primeiras Noções de Educação Cívica (2 Grau). (Ibidem, p.550).

${ }^{8}$ NETO, V. A Questão Religiosa no Parlamento. v.I (1821-1910). Lisboa: Divisão de Edições da Assembleia da República; Texto Editores, 2009. p.91.

${ }^{9}$ PROENÇA, M. C. A Questão Religiosa no Parlamento. v.II (1910-1926). Lisboa: Divisão de Edições da Assembleia da República; Texto Editores, 2011. p.235.

${ }^{10}$ Segundo Oliveira Marques esse decreto iria afetar 401 casas religiosas entre colégios, hospícios e mosteiros femininos em Portugal e nas colônias. (PROENÇA, 2011, 235).

${ }^{11}$ CATROGA, F. A militância laica e a descristianização da morte em Portugal. v.1. Coimbra: Faculdade de Letras, 1988. p.33.

${ }^{12}$ CATROGA, Fernando. Secularização e laicidade: uma perspectiva histórica e conceptual. Revista de História das Ideias, v.25, p.51-128, 2004. p.91.

13 Telmo Verdelho apud CATROGA, 2006, p.27.

${ }^{14}$ Ressalte-se a importância do binômio conceitual decadência/regeneração na cultura política portuguesa ao longo do século XIX. Para uma discussão desses conceitos e de sua relevância como vetores político-ideológicos no contexto em questão ver PROENÇA, M. C. A Primeira Regeneração: o conceito e a experiência nacional (1820-1823). Lisboa: Livros Horizonte, 1990.

${ }^{15}$ Mais que 'dominado', o espaço escolar precisava ser 'apropriado' pelo republicanismo português. A noção de 'apropriação' do espaço foi desenvolvida em: LEFEBVRE, Henri. La production de l'espace. Paris: Anthropos, 1986.

${ }^{16}$ Sobre os "fundamentos e expectativas que norteavam a laicidade como projeto", diz Catroga: "Parece evidente que este prometia criar as condições para que o indivíduo pudesse ascender, em liberdade (de consciência, de pensamento, religiosa), ao gozo dos seus direitos. Pelo que reivindicava os efeitos da secularização: a separação entre a esfera política e a religiosa, a pública e a privada; a privatização das crenças; a afirmação da autonomia do homem perante a justificação transcendente da ética, do conhecimento e das expectativas humanas" CATROGA, F. Secularização e laicidade: a separação das Igrejas e da Escola. In: PINTASSILGO, J. [et al.] (Org.). História da escola em Portugal e no Brasil: circulação e apropriação de modelos culturais. Lisboa: Colibri, 2006. p.35.

${ }^{17}$ HANSEN, P. S. América: uma utopia republicana para crianças brasileiras. Estudos Históricos, Rio de Janeiro, v.22, n.44, p.504-521, jul.-dez. 2009. 
${ }^{18}$ MATOS, S. C. Para uma história da escola privada em Portugal: da Regeneração ao Estado Novo. In: PINTASSILGO (Org.), 2006, p.262.

${ }^{19}$ CATROGA, F. O republicanismo em Portugal: da formação ao 5 de outubro de 1910. 3.ed. Lisboa: Casa das Letras, 2010. p.19.

${ }^{20}$ PROENÇA, M. C. A republicanização da educação e da escola. In: PEDAGOGIA E EDUCAÇÃO (séculos XX e XXI). Actas dos Encontros de Outono, 25 e 26 nov. 2005. Vila Nova de Famalicão, 2008. p.168.

${ }^{21}$ MOURA, M. L. B. A guerra religiosa na 1 ${ }^{a}$ República. Cruz Quebrada: Ed. Notícias, 2004. p.435-436.

${ }^{22}$ Diário do Governo, 24 out. 1910.

${ }^{23}$ Diário do Governo, 3 jan. 1911.

${ }^{24}$ PERROT, Michelle (Org.). História da vida privada. v.4: da Revolução Francesa à Primeira Guerra. São Paulo: Companhia das Letras, 1999. p.91.

${ }^{25}$ Cf. HANSEN, P. S. Infância como projeto. Nacionalismo, sensibilidades e etapas da vida em Olavo Bilac. In: SIMPÓSIO NACIONAL DE HISTÓRIA, 26. Anpuh, São Paulo, jul. 2011. Anais... Disponível em: www.snh2011.anpuh.org/resources/anais/14/1300631786_ ARQUIVO_Infanciacomoprojeto.pdf.

${ }^{26}$ CONSTITUIÇÃO de 21 ago. 1911. Disponível em: debates.parlamento.pt/Constituicoes_ PDF/CRP-1911.pdf.

${ }^{27}$ Diário do Governo, n.73, 30 mar. 1911.

${ }^{28}$ BARROS, João de. A educação moral na escola primária. Paris-Lisboa: Livr. Aillaud e Bertrand; Rio de Janeiro: Livr. Francisco Alves, 1914. p.19-22.

${ }^{29}$ FONSECA, Tomás da. Ensino laico: educação racionalista e acção confessional. Lisboa-Coimbra: Lúmen, 1923. p.37.

${ }^{30}$ LIMA, Adolfo. Pedagogia sociológica. Lisboa-Porto: Couto Martins-Livraria Progredior, 1936. v.1, p.127.

${ }^{31}$ PINTASSILGO, J. O projecto educativo do republicanismo: o caso português numa perspectiva comparada. Ler História, v.59, p.183-203, 2010. p.187.

${ }^{32}$ OZOUF, Mona. L'École, l'Église et la République: 1871-1914. Paris: Armand Colin, 1963. p.125.

${ }^{33}$ OSÓRIO, Ana de Castro. De como Portugal foi chamado à guerra: História para crianças. Lisboa: Casa Ed. "Para as Crianças”, 1918. p.73.

${ }^{34}$ OSÓRIO, A. C. Os nossos amigos. (Livro de leitura para a $3^{\text {a }}$ classe da Escola Primária). 4.ed. rev. e completada. Lisboa: Lusitânia, 1922. Há no início do livro uma nota da autora explicando que a $1^{\text {a }}$ edição da obra fazia parte do livro A Boa Mãe, aprovado para prêmios escolares no ano de 1908. Entretanto, não consegui verificar se a peça de teatro aqui citada já constava desse livro ou se foi incluída em alguma das edições posteriores, pelo que não é 
Patricia Santos Hansen

possível saber com mais precisão, em relação à república e ao republicanismo, com que contexto o texto dialoga mais especificamente.

${ }^{35}$ MOURA, M. L. B. A guerra religiosa na 1a República. Cruz Quebrada: Ed. Notícias, 2004. p.438.

Artigo recebido em 29 de março de 2012. Aprovado em 3 de julho de 2012. 